\title{
Military Coups d'etat in Nigeria Revisited: A Political and Economic Analysis
}

\section{Julius E. Nyang'oro, University of North Carolina, Chapel Hill}

In the last few years, there seems to have been a radical transformation in African politics South Africa, which for a long time reflected the politics of racial domination, is moving towards multi-racial rule. Formerly one-party states such as Zambia and Kenya recently have held multiparty elections; and authoritarian regimes such as Zaire are now seriously discussing the possibility of pluralist politics. The question that this paper seeks to address is whether the changes taking place are indeed ushering in a new phase of politics in Africa without the prospect of military intervention. Nigeria is used as a case study for examining this question.

\section{Introduction}

In a relatively recent book with a catchy title about the military in the Third World Claude E. Welch, Jr. (1987) discusses an important subject that has occupied the interest of many watchers of the underdeveloped world: the possibility of substituting military coups d'etat as the basic form of change in government. He concludes his study by sounding what I consider to be a realistic but pessimistic note:

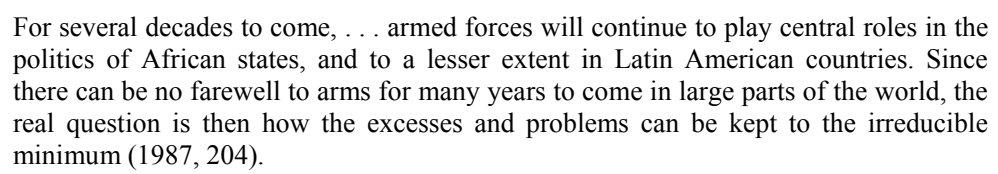

One may wonder why military rule and the phenomenon of the military coup d'etat should be of interest to students of Third World politics in general, and of Africa in particular, when there seems to be a general trend away from single party systems and military regimes in Africa (see MidSouth Political Science Journal 13 [Spring 1992] and Review of African Political Economy No. 54, 1992). Indeed, most of the recent literature on politics in Africa is pre-occupied with the phenomenon of "democratization" (Fatton 1990). The purpose of this article is to introduce a cautionary note against the euphoria of democratization by pointing to the difficulties of transition to civilian rule and to democracy as demonstrated by the case of

Julius E. NyAnG'ORO is Associate Professor and Chairman of African and Afro-American Studies at the University of North Carolina at Chapel Hill.

The American Review of Politics, Vol. 14, Spring, 1993: 129-147

(C)1993 The American Review of Politics 
Nigeria. Although Nigeria presently is in transition to civilian rule, there is no guarantee that democracy can be sustained over the long haul, especially when we consider the military's record in Nigeria since 1966. I will give two examples. First, in April, 1990, when the civilianization process was fully underway in Nigeria, there was a failed coup attempt that resulted in the execution of several dozen military officers (Ihonvbere 1990, 17-39). Second, towards the end of 1992, the Nigerian head of state, General Ibrahim Babangida, effectively took control of the Social Democratic Party (SDP) and the National Republican Convention (NRC), the only two legal parties in the country, by decreeing that all candidates who had participated in the presidential primaries were banned from further participation in Nigerian politics. Babangida's reason for doing so was that he "wasn't prepared to hand over to a bunch of corrupt politicians who had bought their way to victory" (quoted in New African 1993, 7). The target date for the next civilian government now has been set for 27 August 1993. Whether the new target will be met this time is an open question. Thus, I take Welch's pessimistic conclusion as a starting point for my analysis of Nigeria's military coups with special emphasis on the latest two: 31 December 1983 and 27 August 1985.

Writing about military coups in Africa can be a frustrating experience. One cannot be too sure that by the time the writing on a particular coup is done, it would be an analysis of the second most recent coup, as Welch undoubtedly found out while his No Farewell to Arms? was in press. The period between 1979 and 1983 in Nigeria, however, seemed to provide an exception to that rule. Unlike in Ghana or in Burkina Faso, where there had been a succession of military coups over a period of less than two years, the "democratic" experiment in Nigeria under the presidential leadership of Shehu Shagari seemed to hold. The second "successful" national election had been held in August, 1983. By most accounts, Nigeria under the dominance of Shagari's National Party of Nigeria (NPN) was ready to consolidate the success of the democratic experiment into a permanent national institution. Announcement by the military on 31 December 1983 that it had taken over the government, and that the majority of the top civilian officials (including Shagari) were in custody, shattered that optimistic assessment.

This study is meant to be a reevaluation and reassessment of what the scholarship on military intervention in politics in the Third World in general, and Nigeria in particular, points to. The focus on Nigeria is prompted by the fact that the counter coup against General Gowon in 1975 had been justified in part by elements in the military who argued that Gowon was about to renege on a promise of a return to civilian rule. Indeed, the regimes of General Murtala Muhammed and General Obasanjo between 
1975 and 1979 had staked their reputation on the return to civilian rule. The fact that 31 December 1983 ushered in a new military regime after only four years of civilian rule makes Nigeria an interesting case study that may enlighten us on the role of the military in other African countries.

\section{Toward a Theory of Military Intervention}

In an earlier study of military intervention and political change in Africa, Welch summarized what he thought were the reasons for intervention: (1) the declining prestige of the major political parties; (2) schism among prominent politicians; (3) lessened likelihood of external intervention in the event of military uprising; (4) "contagion" from seizures of control by the military in other African countries; (5) economic malaise by the government leading to "austerity" policies thus aggravating negatively affected populations; (6) corruption and inefficiency of government and party officials; and (7) heightened awareness within the army of its power to influence or displace political leaders. In short, "the failure of political parties to achieve their objectives of change and to maintain widespread popular enthusiasm helped prepare the way for army intervention" (1970, 3-4). The problem lay in the nature of political and social organization in society.

Five years later, with slight modification, John S. Fitch made the same point as Welch. Fitch's study, however, was directed toward Latin American societies in general, and especially in reference to Ecuador (1975, 173-196). In his study, Fitch saw the coup d'etat as the culmination of two interrelated political processes: (1) the outcome of a decision within the military to intervene, and (2) a lack of support for the existing government from the politicized sectors of society. In an attempt to develop a model of the coup d'etat, Fitch theorized that

\footnotetext{
[the] coup d'etat is the outcome of the interaction over time of many elements of the social, economic, and political context of the particular country in question. If the reality being studied is relatively nondecomposable into noninteracting sets of variables, the ... meaning of any detail depends on its relation to the whole context of which it is a part $(1975,174)$.
}

Fitch's model contained six factors or variables: four socio-economic population groups, the government, and the military. He focused on two interrelated processes: the loss of civilian support by the government, and the decision of the military to replace the existing authority in a coup d'etat. In his study of Latin American coups, Fitch found that there was a direct relationship between the two processes. Subsequently, in a more refined model of the military coup, Fitch constructed a set of variables that 
contained the essentials of his previous (1975) analysis and of Welch's (1970) assessment.

In his latter work, Fitch noted that in a highly charged political and military environment, securing systematic empirical data on the political behavior of military officers is always difficult. This is due to the obvious reason that nothing is certain whenever there is a possibility of military intervention. However, for him,

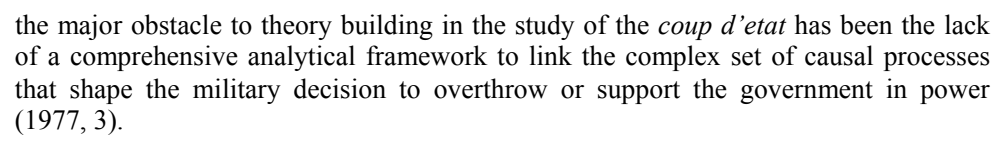

He thus argued that the first logical step in building a theory of military intervention should be the specification of the decision criteria by which the armed forces judge whether at any point a particular government should be supported or overthrown in a coup d'etat. The secondary consideration in this regard would be the military's assessment of the legitimacy of irregular changes of government as a response to political crises, and what political outcomes should be anticipated by the military after the coup d'etat.

Consideration of the works of Welch and Fitch as a background to the study of coups d'etat in Africa in general, and in Nigeria in particular, is warranted for several reasons. These works quite fairly represent what might be termed the "developmentalist" or "modernization" school's standard theoretical analysis of military intervention. Based on simple causal analysis, Fitch's work on Latin America and Welch's work on Africa provide us with illuminating illustrations of civil-military relations in their various facets. They do this through what Fitch calls the "contextual approach," which gives attention

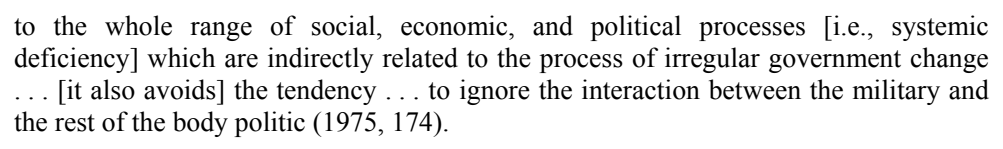

While it is essential that the interaction between the military and the rest of the body politic (i.e., systemic deficiency) occupy an important position in the analysis of military coups, others have argued that it may not be necessarily valid for that relationship to occupy the central position, the way it has been emphasized by studies of the developmentalist tradition (see, for example, Finer 1962; Huntington 1967, 1968; and Janowitz 1964). Samuel Decalo, for example, has suggested that the contention that coups occur as a result of systemic deficiencies grossly lacks explanatory value. According 
to Decalo, the core analytic flaw of the developmentalist approach is the confusion of the very real and existing systemic tensions in African states with other factors lodged in the internal dynamics of the officer corps. Decalo concludes by saying that it is both simplistic and empirically erroneous to relegate coups in Africa to the status of a dependent variable, that, to put it simply (in Huntingtonian terms), is a function of the political weakness and structural fragility of African states and the failings of African civilian elites (Decalo 1977, 5-37).

However, as much as Decalo may want to dissociate himself from what may be considered a developmentalist (systemic) argument, he does not succeed. In his analysis, Decalo argues that coups in Africa are a result of the inability of the officer corps to provide a coherent organizational framework that may form the basis of a stable and non-interventionist army due to the officer corps' varied allegiances. He further states that

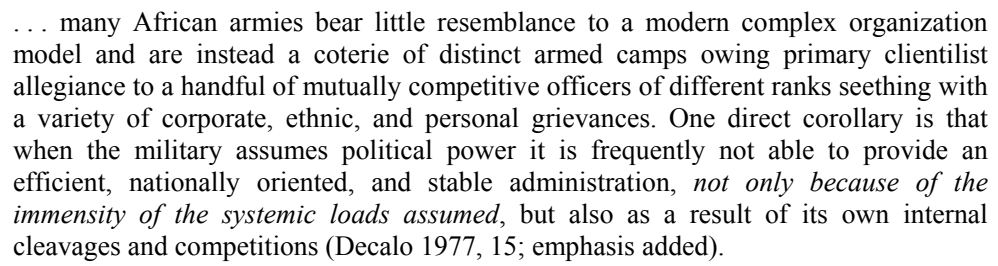

But Decalo's argument is a circular one: above, he in effect says that cleavages in the ranks of the officer corps are systemic in nature, that is, they reflect cleavages (class, ethnicity, nationality, regional, etc.) in society, which in essence is Huntington et al.'s argument on the systemic origin of coups d'etat in the Third World. His critique of systemic approaches to the study of military coups thus is not necessarily a compelling one. His own reference to societal factors suggests that there cannot be a substitute for systemic analysis if a comprehensive understanding of the military coup is to be achieved. Part of the argument that I seek to develop here is that the developmentalist approach, useful as it may be, only partially explains the nature of military coups in the Third World. This arises out of an omission of two critical variables: the nature of the peripheral economy (which dialectically relates to both the political and social systems); and the international dimension, both political and economic. Developmentalist analysis inherently assumes the autonomy of internal (peripheral) political and social systems. The most extreme case is perhaps represented by Tony Smith $(1979,247-288){ }^{2}$ However, numerous studies have demonstrated the illusory nature of the autonomy argument with reference to Third World economies (see for example, Ziemann and Lanzendorfer 1977; FitzGerald 
1977; Duvall et al., 1981; Hamilton 1982; and Blomström and Hettne 1984.) Therefore, we take the arguments on the systemic origin of military coups and the historically determined relationships between peripheral countries and the international economy as our point of departure in the analysis of military coups in Nigeria.

\section{Nigeria's Political Economy Reconsidered}

The late Dudley Seers suggested that the most appropriate way to determine whether development is taking place in a country is to look at what has been happening to poverty, unemployment, and inequality under conditions of increased material output (Seers 1979). According to Seers, the decrease in poverty, unemployment and inequality also will reflect the nature of class relations in society, with the need for reducing misery for the affected population being a matter of conscious choice:

... development in the Third World has to involve a conscious choice, whether to remain fully in the capitalist system and hope to achieve the goal of general life improvement or devise some other formula (Seers, 1969, 3).

In any case, for that objective to be realized, Seers suggested that there has to be: (1) an increase in material production, (2) better socio-economic organization to improve efficiency, (3) an explicit political determination of the process of change, and (4) a general commitment and understanding of where everyone is going in terms of societal goals. Systemic theories of social change argue that unless the above objectives are realized, there is bound to be political instability that may lead to military coups.

Most recent studies of Nigeria's contemporary political economy have suggested that none of the above objectives, with the exception of an aggregate increase in material production, has been met in Nigeria since independence. ${ }^{3}$ Indeed, Douglas Rimmer has demonstrated that since the initial postindependence national development plan, considerations suggested by Seers have received little attention. According to Rimmer:

\footnotetext{
Distributive considerations received sparing mention in the plan of 1962-1968, though there was reference among the overall objectives to achievement of a more equitable distribution of income both among people and among regions ... [Top government bureaucrats] thought a good case could be made that premature preoccupation with equity problems will backfire and prevent any development from taking place.... The productiveness of the economy and the autonomy of the nation were emphasized; the distribution of welfare was not ... it was regarded as the highest importance that the economic development of Nigeria should as much as possible be removed from the political arena (Rimmer 1981, 31-32; emphasis added).
} 
The unrealistic nature of the government plan can first be seen through its assumption of the "non-political" character of the development process. With pre-independence regional and ethnic rivalry in Nigeria, the apparent rigging of the national censes in 1952 and 1962/63, and widespread violence in many parts of the country, the political character of development planning should have been obvious even for the "non-political" bureaucrats. We need to remind ourselves that the state (of which the government is but one aspect) is a political reproduction institution. As such, it is the contradictory representation of social unity and is determined by the complex relationships within society (classes, ethnic groups, nationalities, etc.) that are the expression of the social reproduction process. Thus the denial of the essentially political character of the government obscures the nature of societal organization. ${ }^{4}$

In any case, the censes of 1952 and 1962/63 and the problems associated with the final count, i.e., the distribution of political power and ultimately the distribution of economic benefits by region, should have been a warning to those who had entertained the illusory idea of the non-political nature of economic planning. The 1962/63 census had been conducted under the auspices of a civilian government. The first census after the 1967-70 civil war, however, was conducted under military rule. As Valerie Bennett and A.H.M. Kirk-Greene have noted:

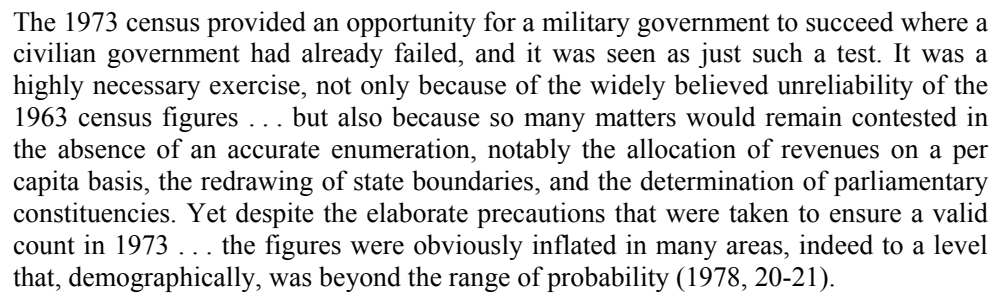
civilian government had already failed, and it was seen as just such a test. It was a highly necessary exercise, not only because of the widely believed unreliability of the 1963 census figures ... but also because so many matters would remain contested in the absence of an accurate enumeration, notably the allocation of revenues on a per capita basis, the redrawing of state boundaries, and the determination of parliamentary constituencies. Yet despite the elaborate precautions that were taken to ensure a valid count in $1973 \ldots$ the figures were obviously inflated in many areas, indeed to a level that, demographically, was beyond the range of probability $(1978,20-21)$.

Thus, in failing to provide a credible census figure, the military regime of General Gowon simply replicated the failure of the previous civilian regime. Even today, the census issue is still a hotly debated one in Nigeria. The current military regime of General Ibrahim Babangida staked its reputation on a return to civilian rule by 1992, but only after a census has been held. Indeed, a census was held in 1992 with the government announcing a preliminary figure of 88.8 million people. Immediately after the announcement of this figure, there were complaints of an undercount, especially from people in the former Eastern and Western regions who continue to see the census as a political instrument of domination by the predominantly Moslem Northern region. One is inclined to doubt the accuracy of this figure if we 
take into account the fact that the 1991 World Bank Report estimated Nigeria's total population to be 113.8 million in mid-1989 (World Bank 1991, 204). Given the miserable track record on the census, it would not be a surprise if the current regime postpones a return to civilian rule as the prospects of conducting a respectable census cannot be guaranteed. When General Babangida took over in August 1985, the projected year for a return to civilian rule was 1990 . The subsequent change to 1992 was a fair warning of the difficulties involved in such an exercise. The announcement in late 1992 that the new date for a return to civilian rule would be August 27, 1993 simply confirmed everybody's worst fears (New African 1993, 7-11).

In purely economic terms, signs of trouble have been evident since independence. Nigeria's economic statistics compiled and analyzed by Rimmer (1981, 20, 32, 41) and subsequently replicated and confirmed by more recent studies show that despite increased material production (in aggregate terms) between the 1950s and early 1980 s, there has been a contraction in every set of gross domestic product estimates in the ratio of private consumption expenditures and corresponding growth in the ratios of capital formation and government consumption. In short, the Nigerian people have been getting poorer in both absolute and relative terms while the state machinery has been getting top-heavy. More fundamental, however, has been the struggle within Nigeria to acquire access to the instrumentalities of state power as the basis of politics and economic influence. If the ultimate reward in gaining power is control of the coercive machinery, then the only way power can change hands is through counter-coercion (Falola and Ihonvbere, 1985).

The apparent centrality of the state in Nigeria's political economy makes the struggle to control it even more intense, with politics viewed more as a zero-sum game. But it should be recalled that despite the relationship that Nigeria has with the international capitalist world, internal politics are still practiced in a prebendal form. Richard A. Joseph defines prebendal politics in Nigeria as those

patterns of political behavior which reflect as their justifying principle that the offices of the existing state may be competed for and then utilized for the personal benefit of office-holders as well as that of their reference or support group $(1984,30){ }^{5}$

The personalization of state offices leads to the ubiquitous problems of corruption in Nigeria and constantly anxious soldiers with a justification for overthrowing the government. It must be added that the personalization of state office is not confined to the civilians but rather pervades the military institution itself (Welch, 1987, 6). 


\section{Nigeria and the International Economy}

The international dimension of Nigeria's political economy and its influence on military coups cannot be ignored, especially given Nigeria's reliance on only one export commodity (oil). In general terms, it is important to recognize the linkages between Nigeria's oil economy, the state's centrality in the organization of the oil industry, and the nature of class relations in society that emerge given the uneven nature of the effects of the oil economy on Nigeria's population (Turner 1978).

The dependency model, despite its many weaknesses, may be a useful tool for understanding the international dimension of Nigeria's economy. ${ }^{6}$ Nigeria, like many other Third World countries, is underdeveloped. The dependency model predicts that under situations of dependency, i.e., when internal (peripheral) production is predicated upon demands of the international economy (as Nigeria's oil is), bottlenecks both in production and consumption are bound to develop. And since for the most part the stimulus for production is outside the peripheral territory, solutions to the bottlenecks (assuming the parameters of the economic relationships remain constant) cannot be found internally. Nigeria found itself in such a situation during the two years prior to the 31 December 1983 coup. With the world price of crude oil declining on one hand, and declining agricultural production, increased unemployment, unabated importation (rather than industrialization), and thence increased government capacity for consumption on the other hand, something was bound to snap. The highly irregular elections of late 1983 simply provided a convenient excuse for the military's re-intervention.

A rapidly growing school of thought in Nigeria squarely places Nigeria's frequent military intervention on the inability of the Nigerian bourgeoisie to develop and sustain a capitalist system of production similar to the one found in the West. Based on dependency arguments, this school of thought views both the Nigerian state and the local classes that control it as basically subordinate to the international system. Thus Toyin Falola and Julius Ihonvbere argue that:

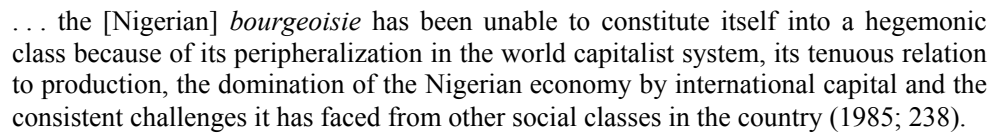

According to Falola and Ihonvbere, military coups in Nigeria thus can be understood as a strategic response of the classes that control the state (but are under constant challenge from the oppressed classes) to crises, such as the economic crisis that faced Nigeria with the decline of world oil prices. ${ }^{7}$ 
This line of reasoning suggests that as long as Nigeria continues to be a dependent, underdeveloped country lacking self-sustaining industrialization, frequent military coups are inevitable and serve as an internal self-correcting mechanism for a regime under constant crisis. This argument is also advanced in a slightly different form by Pat McGowan and Thomas $\mathrm{H}$. Johnson, two scholars within the modernization tradition (McGowan and Johnson 1984, 1986).

The disarticulated economy that results from underdevelopment also has consequences for income distribution. The politics of income distribution operate at the level of the state and the rewards associated with the control of the state seem to propel competing elements within the military to use force to gain such control. In terms of income distribution in Nigeria, V.P. Diejomaoh and E.C. Anusionwu have estimated that nothing much has changed since the first comprehensive surveys were made in the early 1960s. If anything, the distribution of income has worsened over the years (Okowa 1985, 71-81; Ihonvbere 1990). This fact points to one of Nigeria's main problems because it creates pressure for the state to satisfy the economic needs of the majority of its population that is affected adversely by high income inequities. It also indicates the failure of Nigeria to satisfy one of Seers' cardinal principles in measuring development, i.e., reduction of social inequality.

Diejomaoh and Anusionwu further found that regional resource allocations exhibit inequalities:

\footnotetext{
With regard to regional inequalities, it is essential that the federal government use its position and spending powers to further reduce regional inequalities because they are currently too high. The state governments themselves need to pay increased attention to the reduction of territorial inequalities within the state $(1981,105)$.
}

Thus, there are two types of inequalities - social and regional - and the federal government must play an important role in reducing both types of inequalities. The fact that the federal government has such a role in the distribution of resources leads to political pre-occupation with control of the government. All aspects of life become "overpoliticized," as seems to have been the case in Nigeria. At one level, it is plausible to argue that the creation of more states in Nigeria is a response to the continued demand upon the federal government for more equitable distribution of national resources. Nigeria now has thirty states and there are still demands for more- a dramatic progression from four regions (Eastern, Western, Midwest and Northern) at the time of independence. In a harsh indictment of the post-independence Nigerian state, but especially of the post-1979 civilian regime, Larry Diamond concluded that 


\begin{abstract}
The primary source of economic crisis and political decay in Nigeria today is the lengthening shadow of the state over every other realm of society. Since independence, the state has been the chief arena for the accumulation of wealth and the acquisition of resources, and has been becoming so ever more decisively. Too much of the country's wealth is mediated through government contracts, jobs, import licenses, development projects and so on. Too little is accessible through any activity substantially independent of the state. As a result, power has replaced effort as the basis of social reward (1984a, 915).
\end{abstract}

Diamond's indictment of the Nigerian state, however, misses the larger point. The characteristics of the state described above are not peculiarly Nigerian. One would be hard pressed to cite a Third World country, and especially an African country, where the role of the state "over every other realm of society" is not a matter of everyday life. Probably one is on safer ground talking about degrees of pervasiveness of state control, rather than merely its existence. ${ }^{8}$ This point in effect takes us full-circle, back to dependency theory's argument regarding underdeveloped state structures, and to Joseph's concept of prebendalism. Dependency theory argues that due to external economic penetration, and underdevelopment in general, governments in peripheral capitalist countries involve themselves in the economy on an increasingly large scale and in the process produce what is a most distinguishing feature of peripheral capitalism-namely, state-dominated capitalism. The emergence of such a state thus is inevitable under conditions of dependency and underdevelopment (Duvall et al. 1981, 335). It seems that Diamond is still on shaky ground when he argues that

Fundamentally, the [31 December 1983] coup was not caused by the world recession, by authoritarian tendencies, or by hunger for power on the part of military officers. The overthrow of the Second Republic was caused by its politicians. By their corruption and mismanagement, their hubris and abuse of power, and their violent and fraudulent pursuit of power, they brought about their own demise (1984a, 915).

Indeed, Diamond's argument is further nullified by his own statement that "(f)or a nation that depends on oil for more than 90 percent of its foreign exchange earnings and for 80 percent of its government revenue, the sharp drop in world demand for oil could not have been anything but disastrous" (1984b, 9). Here Diamond makes the unavoidable link between Nigeria's overall economic crisis and the international economy. No realistic assessment of Nigeria's problems can afford not to. This analysis suggests that any attempt at understanding Nigerian politics has to include the international dimension of the economy. The international connection invariably manifests itself in the way politics is conducted internally, albeit in an inconsistent pattern depending on the issue at stake. As several studies show, profit-making in Nigeria continues to depend on collaboration with foreign 
firms and on the favor of the state. The state continues to control access to money contracts and commercial opportunities (Young 1982, 230; Biersteker 1987). Politics thus becomes a struggle for the control of these resources. But these resources also are the means by which politics is carried out. Here lies the basis for corruption. In other words, corruption, waste, mismanagement, etc. are not inherent, as Diamond's analysis seems to suggest. Rather, they derive from state involvement in the economy, which further has its origins in underdevelopment itself.

\section{The Aftermath of the Two Most Recent Coups in Nigeria}

In a speech to the nation a few days after the 31 December 1983 coup, General Buhari, the new military leader, stated that the change in government had been necessary in order to put an end to the "serious economic predicaments and the crisis of confidence" that had afflicted the nation as a result of civilian rule. He went on to cite the mismanagement of the economy, rigged elections that "could be anything but free and fair," and corruption and indiscipline as the reasons for the predicament and crisis of confidence (West Africa 9 January 1984, 9).

Buhari's misgivings about corruption, inefficiency and general political anarchy in Nigeria invoked the memory of what happened during the first military coup in Nigeria on 15-16 January 1966. A statement issued by Major Nzeogwu, leader of the first coup, said in part:

\footnotetext{
We wanted to get rid of rotten and corrupt ministers, political parties, trade unions and the whole clumsy apparatus of the federal system.... The military has taken over to bring an end to gangsterism and disorder, corruption and despotism. My compatriots, you will no longer need to be ashamed to be Nigerians (Miners 1971, 177).
}

On 27 August 1985, Major-General Ibrahim Babangida overthrew the regime of General Buhari. Africa Now $(1985,9)$ reported the coup as follows:

The popular enthusiasm accorded Buhari after the overthrow of President Shehu Shagari had quickly evaporated. Many of the problems used to justify the military takeover from the civilians persisted and fundamental change did not appear on the horizon. The continued deterioration in the standard of living, suppression and apparent insensitivity of the government created an explosive situation.

General Babangida went on to say things about General Buhari's regime that were almost identical to what the latter had said about the regime of Shehu Shagari. The fact that every new regime arriving on the scene points to the same problems raises some fundamental questions about 
Nigeria's political economy, and thereby suggests that the prospects for a change to civilian rule are as dim as ever. It also raises the question of the nature of leadership and political change in Nigeria over the past quarter century (Oyediran and Agbuje 1991).

One striking feature of Nigeria's top civilian political leadership is that, as of 31 December 1983, it had not changed fundamentally in two decades. For example, the four major presidential candidates in 1983 all had ties to the pre-1966 government that was overthrown by Major Nzeogwu and subsequently replaced by General Ironsi. Shagari (National Party of Nigeria) first entered parliament in 1954, representing Sokoto West. In 1959, Tafawa Balewa appointed him acting federal minister of trade and industry, thus assuring him of a place in the elite stratum of the federal government. Awolowo (United Party of Nigeria) formed the Action Group in 1951 and subsequently entered the Western House Assembly. In 1959, he became Prime Minister of Western Nigeria. Azikiwe (Nigerian People's Party) entered the Legislative Council in 1948. Before becoming the first GovernorGeneral and then President of Nigeria at independence, he had served as Premier of Eastern Nigeria. Finally, Alhaji Waziri Ibrahim (Great Nigerian People's Party) was first elected to the Federal House of Representatives in 1959, and had been minister of health and economic development between 1962 and 1966. With few exceptions, this has been the general pattern in Nigerian politics. This shows a remarkable continuity in civilian political leadership despite the thirteen year (1966-1979) interlude of military rule.

For the most part, the civilian leadership's perception of political issues and of development in general had not changed radically, given (1) the continuity in political personnel and (2) the generally conservative outlook of the politicians before 1966. The return to civilian rule, if anything, had reinforced their conservative and generally reactionary ideology. Indeed, West Africa Magazine observed how similar the political manifestoes of all the major parties were, which also suggested the irrelevance of the electoral process in general:

What all the documents [Election Manifestoes] have confirmed is that with the possible
exception of the NAP, which claims pretensions to socialist tendencies, there are no
ideological differences between Nigeria's political parties ( 25 July 1983, 1707).

Thus, the 1983 general election was more of a beauty contest than a choice between two or more different policies. But more fundamentally, in practical terms, what this meant was that none of the political parties was adequately equipped (either ideologically or technically) to handle the economic crisis that rapidly was engulfing the country. None of the parties had questioned in serious terms the nature of Nigeria's relation to the 
international economy; neither could any of the major parties offer a solution to the increasing tension between Nigeria and the IMF/World Bank with regard to Nigeria's overexposure on the international financial market and its internal economic policies. In mid-1983, T.M. Shaw summarized Nigeria's predicament as follows:

... the emerging, underlying choice is between renegotiating debt and restructuring the economy. The present [1983] establishment, particularly in a preelection period, prefers the former; those out of power and out of work have more interest in the latter. The basic choice of marginal versus structural reform ... may be more important in the long-run than which of the major parties is successful in the approaching elections (West Africa 25 July 1983, 1707).

Those looking for a radical solution to Nigeria's almost endless political and economic crises were quickly disappointed by what the Buhari administration had to offer. There still was remarkable continuity in top civilian personnel in all government ministries. Indeed, in a revealing account of internal politics in Nigeria, S.G. Ikoku, who prior to the December, 1983 coup had been special advisor to the President on National Assembly Affairs, remarked to his wife after learning the identities of the new rulers: "There is no coup" (Ikoku 1985, 6). This fact alone gives credence to the argument noted earlier that military intervention in Nigeria historically has not threatened the ruling class, nor has it been a substitute for its absence. In many respects, it has tended to represent that class and compensate for its inability to establish itself as a well-integrated hegemonic group. As West Africa noted about the new regime:

\footnotetext{
One thing everyone is sure of ... is that Nigeria is not about to embark on a revolution. People who had expected the issuing of decrees on all aspects of government, have concluded that they will have to wait for some time.... This regime, to the extent that it has given any indications at all, is firmly on the side of continuity (26 January 1984, 101; emphasis added).
}

\section{Conclusion}

The lack of substantive change in policy by Nigerian governments as regimes change back and forth reinforces the perception held by many that the alienation of the majority of the population leaves few options but for a radical transformation of the entire political economy (Onimode 1982; Falola and Ihonvbere 1985; Madunagu 1982). How this transformation can be achieved is still an open question. It is becoming increasingly obvious that the military regimes of General Buhari and General Babangida have not been able to resolve the economic crisis. The IMF/World Bank-inspired 
reforms have hit a snag as they have proved "too harsh for Nigerians to take, and [their] successes too meager to sustain the hope of future economic redemption" (Africa Confidential 8 January 1988, 1; see also Ekwe-Ekwe 1985). This has led to criticism of the current military regime by retired military officers, including former head of state General Olusegun Obasanjo. The so-called "home grown" economic reforms currently underway promise little in terms of overall improvement in the lives of the majority of the population (Ihonvbere 1990). The latter months of 1992 saw a sharp increase in the rate of inflation and further pressure to devalue the national currency. Foreign investment has been slow to re-enter the Nigerian market and the "formal" economy is continually on the brink of collapse. The poorest segments of the population continue to bear the worst of it (New African 1993).

Given the frequency with which Nigeria has been ruled by military regimes, the 31 December 1983 coup unleashed a debate that has yet to be resolved on the future role of the military in Nigerian politics. The concept of diarchy slowly but surely has creeped into the political discourse. In the context of Nigeria, diarchy means government by two interest groups-viz., the military and the civilians - that are each autonomous and yet also interdependent with the other group for purposes of governing. The concept itself suggests the permanence of the military in Nigerian politics. As S.G. Ikoku stated after the 31 December 1983 coup:

\footnotetext{
The fourth coup d'etat constitutes a historic turning point in Nigeria's political evolution. All subsequent coups if at all, will merely confirm and energize this conclusion. There is little likelihood of a return to the era when the conduct of our national affairs was the exclusive concern of a civil political class, with a supercilious military at the ready to defend our territorial integrity. Such a return to the modus operandi ante will be neither feasible in a permanent sense nor in the national interest $(1985,37)$.
}

Ikoku argues that the reasons for the diarchy imperative are dual: first, the officer corps of the Nigerian armed forces is too deeply politicized to stay out; second, the Nigerian military is the only institution with the capacity to enforce Nigerian unity. Indeed, this argument now has seeped into the debate on democracy in Nigeria as some prominent members of the academy do not seem to see any contradiction between continued military presence in government and the overall development of democratic institutions in the country (Ibrahim 1986; see also Nwako 1985 and Nuta 1985). With such rationalization it is difficult to see how the military easily could disengage itself from politics, or even would have the incentive to do so. As we pointed out at the beginning of this essay, Claude E. Welch, Jr. is 
concerned about the prospects for long-term disengagement, and believes that

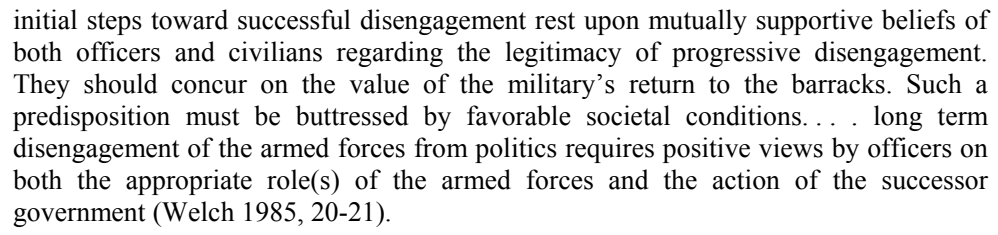

Given the attitude of the Nigerian military leaders, some members of the academy, and politicians such as Ikoku, there will be no "farewell to arms" in Nigeria any time soon, despite talk of "democratization" now underway in Nigeria in specific, and in Africa in general.

\begin{abstract}
ADDENDUM
The above essay was completed in early 1993. The essay noted that presidential elections which had been scheduled for spring 1993 had been postponed by the military government of General Ibrahim Babangida because of what the government claimed to be "highly rigged" primaries. Those who had run in the primaries were banned from becoming candidates in subsequent elections. A new date for the presidential elections was then set for 12 June 1993.

The presidential election of 12 June featured two very wealthy businessmen representing the country" two officially sanctioned political parties. The candidates were Chief Moshed Abiola for the "left of center" Social Democratic Party and Alhaji Bashir Tofa for the "right of center" National Republican Convention. Both had won the right to represent their respective parties at party conventions held on 27 March 1993.

The elections were held as scheduled on 12 June. By law, election results were supposed to be announced within a specified time period. Failure to do so would result in the results being nullified. Soon after the elections the National Electoral Commission, which had been given broad powers to ensure fair elections, became involved in court cases arising out of accusations of irregularities of all kinds during the elections. Various courts then issued injunctions, in essence making it impossible for the results to be announced within two weeks of the election. On 23 June 1993 the military government nullified the election amid general confusion as to what the next step will be for either the political parties or the military government. Unofficial results had indicated that Chief Abiola of SDP had won nineteen of thirty states, and about 50 percent of the total vote. Either
\end{abstract}


way, the fears I had expressed at the end of my essay have been realized. It seems that there will be no farewell to arms in Nigeria any time soon.

\section{NOTES}

${ }^{1}$ Incidentally, Welch now prefers the concept of military "participation" as opposed to "intervention." See chapter 1 of his No Farewell to Arms? This formulation also is advocated for Latin America by Howard Wiarda in his study, Critical Elections and Critical Coups (1978).

${ }^{2}$ I do not wish to overstate this point. Most developmentalist analyses include some aspect of the international dimension. The problem, however, is that the international dimension often is mentioned as an afterthought in these studies; hence my critique.

${ }^{3}$ At the moment studies are beginning to show that even aggregate increase in material production has stagnated substantially since the mid-1980s, leading to the introduction of a variety of structural adjustment policies. See, for example, Ihonvbere (1990) and Mosley (1992).

${ }^{4}$ There are several studies that make this point for the more contemporary period. See, for example, Ake (1985) and Watts (1987).

${ }^{5}$ Joseph further develops this thesis in his book, Democracy and Prebendal Politics in Nigeria (1987). The same point also is made by Gavin Williams, in State and Society in Nigeria (1980). (1989).

${ }^{6}$ For a critique of the dependency model, see Seers (1981), Duvall et al. (1981) and Nyang'oro (1982).

${ }^{7}$ For similar arguments see contributions in Ake (1985), Ihonvbere (1990), and Onimode (1982).

${ }^{8}$ For similar arguments see contributions in Ake (1985), Ihonvbere (1990), and Onimode

\section{REFERENCES}

Africa Confidential. 1988. Austerity Reaches Its Limits.

Africa News. 1985. Babangida's New Broom. (September.)

Ake, Claude, ed. 1985. A Political Economy of Nigeria. New York: Longman.

Bennett, Valerie P. and A.H.M. Kirk-Greene. 1978. Back to the Barracks: A Decade of Marking Time. In K. Panter-Brick, ed., Soldiers and Oil: The Political Transformation of Nigeria. London: Frank Cass.

Biersteker, Thomas J. 1987. Multinationals, the State, and Control of the Nigerian Economy. Princeton: Princeton University Press.

Blomström, Magnus and Björn Hettne. 1984. Development Theory in Transition: The Dependency Debate and Beyond. London: Zed.

Decalo, Samuel. 1977. Coups and Army Rule in Africa. New Haven: Yale University Press.

Diamond, Larry. 1984a. Nigeria in Search of Democracy. Foreign Affairs 62: 905-927. . 1984b. The Coup and the Future. Africa Report (March-April).

Diejomaoh, V.P. and E.C. Anusionwu. 1981. Structure of Income Inequality in Nigeria: A Macro Analysis. In Henry Bienen and V.P. Diejomaoh, eds., Inequality and Development in Nigeria. New York: Holmes and Meier.

Duvall, Raymond et al. 1981. A Formal Model of 'Dependencia Theory': Structure and Measurement. In Richard L. Merritt and Bruce M. Russett, eds., From National Development to Global Community. London: George Allen and Unwin.

Ekwe-Ekwe. 1985. The Nigerian Plight: Shagari to Buhari. Third World Quarterly 7, 3.

Falola, Toyin and Julius Ihonvbere. 1985. The Rise and Fall of Nigeria's Second Republic, 1979-84. London: Zed.

Fatton, Robert, Jr. 1990. Liberal Democracy in Africa. Political Science Quarterly 105: 455-473. 
146 | Julius E. Nyang'oro

1989. The State of African Studies and Studies of the African State: The Theoretical Softness of the 'Soft State.' Journal of Asian and African Studies 24: 170-187.

Finer, S.E. 1962. The Man on Horseback. London: Pall Mall.

Fitch, John S. 1975. Toward a Model of the Coup d'Etat in Latin America. In G.D. Brewer and R.D. Brunner, eds., Political Development and Change: A Policy Approach. New York: Free Press.

1977. The Military Coup d'Etat as a Political Process: Ecuador, 1948-1966. Baltimore: The Johns Hopkins University Press.

Fitzgerald, E.V.K. 1977. The State and Economic Development in Latin America. Cambridge: Center for Latin American Studies.

Hamilton, Nora. 1982. The Limits of State Autonomy: Post Revolutionary Mexico. Princeton: Princeton University Press.

Huntington, Samuel P. 1967. The Soldier and the State. Cambridge, MA: Harvard University Press. 1968. Political Order in Changing Societies. New Haven: Yale University Press.

Ibrahim, Jibrin. 1986. The Political Debate and the Struggle for Democracy in Nigeria. Review of African Political Economy 37: 38-48.

Ihonvbere, Julius O. 1990. Structural Adjustment, the April 1990 Coup, and Democratization in Nigeria. Africa Quarterly 29: 17-39.

Ikoku, S.G. 1985. Nigeria's Fourth Coup D'Etat: Options for Modern Statehood. Enugu, Nigeria: Fourth Dimension.

Janowitz, Morris. 1964. The Military in the Political Development of New States. Chicago: University of Chicago Press.

Joseph, Richard A. 1984. Class, State and Prebendal Politics in Nigeria. In Nelson Kasfir, ed., State and Class in Africa. London: Frank Cass.

1987. Democracy and Prebendal Politics in Nigeria: The Rise and Fall of the Second Republic. New York: Cambridge University Press.

Madunagu, Eddie. 1982. Problems of Socialism: The Nigerian Challenge. London: Zed.

McGowan, Pat and Thomas H. Johnson. 1984. African Military Coups d'Etat and the Politics of Underdevelopment: A Quantitative Analysis. Journal of Modern African Studies 22: 633-666. 1984. Sixty Coups in Thirty Years: Further Evidence Regarding African Military Coups d'Etat. Journal of Modern African Studies 24: 539-546.

Midsouth Political Science Journal. 1992. Vol. 13 (Spring).

Miners, N.J. 1971. The Nigerian Army, 1956-1966. London: Methuen.

Mosley, Katharine P. 1992. Seizing the Chance: Economic Crisis and Industrial Restructuring in Nigeria. In Julius E. Nyang'oro and Timothy M. Shaw, eds., Beyond Structural Adjustment in Africa: The Political Economy of Sustainable and Democratic Development. New York: Praeger.

New African. 1993. No. 304 (January).

Nuta, Ikenga. 1985. The Diarchy Proposition. West Africa (April 1): 160-161.

Nwako, Arthur Agwuncha. 1985. Civilianized Soldiers: Army/Civilian Government for Nigeria. Enugu, Nigeria: Fourth Dimension.

Nyang'oro, Julius E. 1989. The State and Capitalist Development in Africa: Declining Political Economies. New York: Praeger. Westview.

Okowa, Willie. 1985. Public Policy and Rural-Urban Distribution of Income in Nigeria. In Claude Ake, ed., A Political Economy of Nigeria. New York: Longman.

Onimode, Bade. 1982. Imperialism and Underdevelopment in Nigeria: The Dialectics of Mass Poverty. London: Zed.

Oyediran, Oyeleye and Adigun Agbaje. 1991. Two Partyism and Democratic Transition in Nigeria. Journal of Modern African Studies 29: 213-235.

Review of African Political Economy. 1992. No. 54.

Rimmer, Douglas. 1981. Development in Nigeria: An Overview. In Henry Bienen and V.P. Diejomaoh, eds., Inequality and Development in Nigeria. New York: Holmes and Meier. 
Rothchild, Donald and Naomi Chazan, eds. 1988. The Precarious Balance: State and Society in Africa. Boulder, CO: Westview.

Seers, Dudley, ed. 1981. Dependency Theory: A Critical Reassessment. London: Frances Pinter. . 1969. The Meaning of Development. International Development Review 11: 2-6.

Smith, Tony. 1979. The Underdevelopment of Development Literature: The Case of Dependency Theory. World Politics 31: 247-288.

Turner, Terisa. 1978. Commercial Capitalism and the 1975 Coup. In K. Panter-Brick, eds., Soldiers and Oil: The Political Transformation of Nigeria. London: Frank Cass.

Watts, Michael, ed. 1987. State, Oil and Agriculture in Nigeria. Berkeley, CA: Institute of International Studies.

Welch, Claude E., Jr. 1987. No Farewell to Arms? Military Disengagement from Politics in Africa and Latin America. Boulder: Westview.

. 1970. The Roots and Implications of Military Intervention. In Claude E. Welch, Jr., ed., Soldier and State in Africa: A Comparative Analysis of Military Intervention and Political Change. Evanston, IL: Northwestern University Press.

West Africa. London. Various Issues.

Williams, Gavin. 1980. State and Society in Nigeria. Idanre, Nigeria: Afrograficta Publishers.

World Bank. 1991. World Development Report. New York: Oxford University Press.

Young, Crawford. 1982. Ideology and Development in Africa. New Haven: Yale University Press.

Ziemann, M. and M. Lanzendorfer. 1977. The State in Peripheral Societies. London: Merlin Press. 
